\title{
Exploring Hydrologic Connections between Tropical Mountain Wetlands and Glacier Recession in Peru's Cordillera Blanca
}

\begin{abstract}
Receding mountain glaciers affect the hydrology of downslope ecosystems with consequences for drinking water, agriculture, and hydropower production. Here we combined land cover derived from satellite imagery and other environmental data from the northern Peruvian Andes into a first differencing regression model to assess wetland hydrologic connectivity. Wetland area was considered the response variable and a variety of land cover, climatic, and stream discharge explanatory variables were tested to evaluate effects of possible hydrologic connectivity. The results indicate that there were two primary spatial driving forces of wetland change in Peru's Cordillera Blanca from 1987 to $1995:$ 1) loss in glacier area was associated with increased wetland area, controlling for other factors; while 2) an increase in mean annual stream discharge in the previous 12 months increased wetland area. The general approach we used expands the ways that connectivity between landscape changes and hydrologic and ecosystem processes can be assessed.
\end{abstract}

Keywords: land change science, climate change, hydrology, tropical glaciers, mountain wetlands

* Corresponding author. Email: mollypolk@utexas.edu 


\section{Introduction}

Landscape change can result from shifting hydrological processes and, in turn, feedbacks through altered evapotranspiration, runoff, and water storage can further influence landscape arrangement and composition. Landscape changes detected by satellite observations provide insights into the hydrologic connectivity that characterizes these processes, although quantifying the effects is complicated by high natural variability, typically unmeasured groundwater interconnections, and incomplete data archives (DeFries \& Eshleman, 2004; Wohl et al., 2012). In this research, we adapt an econometric model to examine the influence of glacier retreat on downslope wetland ecosystems. To do this, we utilized an historic stream discharge dataset for selected Santa River watersheds in the Cordillera Blanca of northern Peru and compared it to land cover change derived from satellite imagery. The general approach can be adapted to study many other situations where the relationship between hydrologic connectivity and environmental drivers of change is in need of assessment (e.g. Ponette-González et al., 2014).

In joining econometric modeling with spatial categorical data, the explanatory variables can be conceived of as spatial driving forces, with ancillary datasets representing variables such as precipitation, evapotranspiration, or topography that can further specify the model (Chowdhury, 2006). Response variables can similarly be extracted from spatial categorical data derived from remotely-sensed imagery. Multiple logistic regression is often used (Cui, Gao, Zhou, \& Mu, 2014; Mertens \& Lambin, 2000), which provides a probability estimate of the effect of the explanatory variables on the response variable (Wooldridge, 2009). Another technique involves panel data and fixed effects regression (Andreß, Golsch, \& Schmidt, 2012), which relies on a simple design: make each observation its own control. In this case, for each watershed we can estimate the effects of explanatory variables and control for unobserved 
variables. This is useful in studies where a non-experimental design is the only available strategy to evaluate interconnections. The response variable must be measured on two occasions at a minimum and the measurements must be directly comparable over time; additionally, the explanatory variables must exhibit variation across time (Allison, 2009). In contrast to multiple logistic regression that measures a probability response for change from one land cover to another, fixed effects regression generates an estimate of the relative effect of an explanatory variable over time, thus explicitly estimating how changes in the explanatory variables affect the response variable temporally (Wooldridge, 2009); doing so eliminates time-constant effects, both observed and unobserved. When two time periods are used, the technique is referred to as first differencing (Wooldridge, 2009).

Here we utilize the changes in wetland area as a way to evaluate hydrologic connectivity as affected by the glaciers themselves, and by other hydrologic and climatologic variables. Like many glaciated mountains nowadays, ice cover in the Cordillera Blanca is decreasing (Kaser, 1999; Rabatel et al., 2013; Thompson et al., 2006). Permanent ice cover declined from $723 \mathrm{~km}^{2}$ in 1970 (Kaser, Ames, \& Zamora, 1990) to $482 \mathrm{~km}^{2}$ by 2010 (Burns \& Nolin, 2014). Ice loss in the high Andes is associated with multiple social and biophysical consequences including changing water supplies for human uses as well as ecosystem integrity (Bradley et al. 2006), a coupled relationship that has been observed globally (Viviroli et al. 2007). The effects on stream discharge are often region-specific based on climatological differences. There is, however, a widely accepted conceptual model that broadly describes the impact of glacier recession on stream discharge. Introduced by Braun et al. (2000), the model has been reproduced in a number of studies with each contributing slight variations (Hock, Jansson, \& Braun, 2005; Jansson, Hock, \& Schneider, 2003; Moore et al., 2009; Nolin, Phillippe, Jefferson, \& Lewis, 2010; Rees 
\& Collins, 2006). More recently conceptualized as “peak water” by Carey et al. (2014), the model characterizes the impact of glacier retreat on surface hydrology by an initial increase in annual stream discharge during the early stages of deglaciation, followed by a decline in stream discharge as the glacier volume becomes too small to sustain flows. In addition to change in mean annual discharge, the hydrological transformation is characterized by an increase in discharge variability (Collins, 2008).

Recently, Baraer et al. (2012) have explored the peak water concept for the specific case of the Cordillera Blanca. Their study suggests that most of the streams in the Cordillera Blanca have undergone a decline in annual and dry season stream discharge since the 1980s that is related to glacier retreat. In addition to decreasing mean annual discharge, an increase in the annual variability of flows was observed. The researchers predicted that when glaciers lose their hydrological influence, yearly stream discharge should stabilize at a slightly lower level than earlier and dry season discharge is anticipated to be lower. Baraer et al. (2012) corroborated conclusions from previous studies focusing on the Cordillera Blanca: Juen et al. (2007) and Vuille et al. (2008) showed that reductions in glacier area may result in no major net change in annual total runoff, but seasonal variation should increase. In 2005, Pouyaud et al. (2005) projected a similar stream discharge evolution, but in a different timeframe.

Much of the high mountain landscapes within the Cordillera Blanca are within the boundary of Huascarán National Park where valley peatlands and wet meadows (together referred to herein as wetlands) form patches that are changing spatially. A case study from one valley, Quilcayhuanca, evaluated changes from 2000 to 2011. Over the 11-year interval, wetlands in Quilcayhuanca became smaller and more fragmented (Bury et al., 2013). Other research performed at the scale of the park (all valleys inside the park) found that wetland 
spatiotemporal change trends are nonlinear with wetlands increasing in area from 1987 to 1999, then decreasing in area from 1999 to 2010 (Polk, 2016). Relevant to this study is that in 1987, wetland occupied 12,402 hectares and by 1995 , wetland had increased to 13,858 hectares, an 11.7\% increase over 8 years (Polk, 2016). The wetlands receive input from groundwater, precipitation, and surface water flows, while they also contribute to aquifers and streamflow (Gordon et al., 2015; Maldonado Fonkén, 2015). Outflows from peatlands are seasonally variable, increasing during rainy periods and decreasing in the dry season when evapotranspiration is higher and inputs are lower (Rydin \& Jeglum, 2013).

We explored the possible statistical relationships between area of wetlands and shifting hydrologic processes by testing seven hypotheses (Table 1). Because wetlands are spatially proximal to glaciers in the study area (Figure 1), change in glacier area should be associated with change in wetland area (H1). In most Cordillera Blanca watersheds, proglacial lakes dammed by moraines (or engineered impoundments) store glacier meltwater. Ice loss is associated with increasing lake surface area and volume (Emmer, Vilímek, Klimeš, \& Cochachin, 2014), so wetlands could be changing as a statistical function of both glaciers and lakes (H2). Baraer et al. (2012) showed that the Santa River discharge is decreasing while variability is increasing as glaciers recede, so changes in discharge and glacier area could be used jointly to estimate wetland area change (H3). By combining those three hypotheses, changes in glacier area, lake area, and discharge can be used as explanatory variables (H4). Some wetlands in the Peruvian Andes are thought to be groundwater-supported fens (e.g. Cooper et al., 2010), but in the study area wetlands may be maintained only by precipitation (bogs). As such, H5 introduces a lagged precipitation variable in place of lake area to address this possibility, and maintains the relationship between glacier area and discharge; a lagged variable is used because some water 
held in wetlands may be stored from prior rainy seasons, although the residence time is unknown (Gordon et al., 2015). In H6, we include four variables, changes in glacier area, discharge, lake area, and precipitation, to estimate wetland change. Finally, it may be that changing discharge and precipitation may alone predict wetland change $(\mathrm{H} 7)$, as glaciers recede, assuming that the influence of meltwater will diminish and precipitation will be the key driver of streamflow (Baraer et al., 2012; Mark \& Seltzer, 2003).

Table 1. Hypotheses exploring the relationships among changing wetlands and other variables.

H1 Glacier recession has an effect on wetland area; $\Delta \beta_{\text {Glacier_area }} \neq 0$.

H2 Glacier recession and changing lake area have an effect on wetland area; $\Delta \beta_{\text {Glacier_area }} \neq 0$ and $\Delta \beta_{\text {Lake_area }} \neq 0$.

H3 Glacier recession and decreased discharge have an effect on wetland area; $\Delta \beta_{\text {Glacier_area }} \neq 0$ and $\Delta \beta_{\text {discharge }} \neq 0$.

H4 Glacier recession, decreased discharge, and change in lake area have an effect on wetland area; $\Delta \beta_{\text {Glacier_area }} \neq 0, \Delta \beta_{\text {discharge }} \neq 0, \Delta \beta_{\text {Lake_area }} \neq 0$.

H5 Glacier recession, decreased discharge, and change in prior precipitation have an effect on wetland area; $\Delta \beta_{\text {Glacier_area }} \neq 0, \Delta \beta_{\text {discharge }} \neq 0, \Delta \beta_{\text {ppt }} \neq 0$.

H6 Glacier recession, decreased discharge, change in lake area, and change in prior precipitation have an effect on wetland area; $\Delta \beta_{\text {Glacier_area }} \neq 0$, $\Delta \beta_{\text {discharge }} \neq 0, \Delta \beta_{\text {lake_area }} \neq 0, \Delta \beta_{\text {ppt }} \neq 0$.

H7 Decreased discharge and change in prior precipitation have an effect on wetland area; $\Delta \beta_{\text {discharge }} \neq 0, \Delta \beta_{\text {ppt }} \neq 0$. 

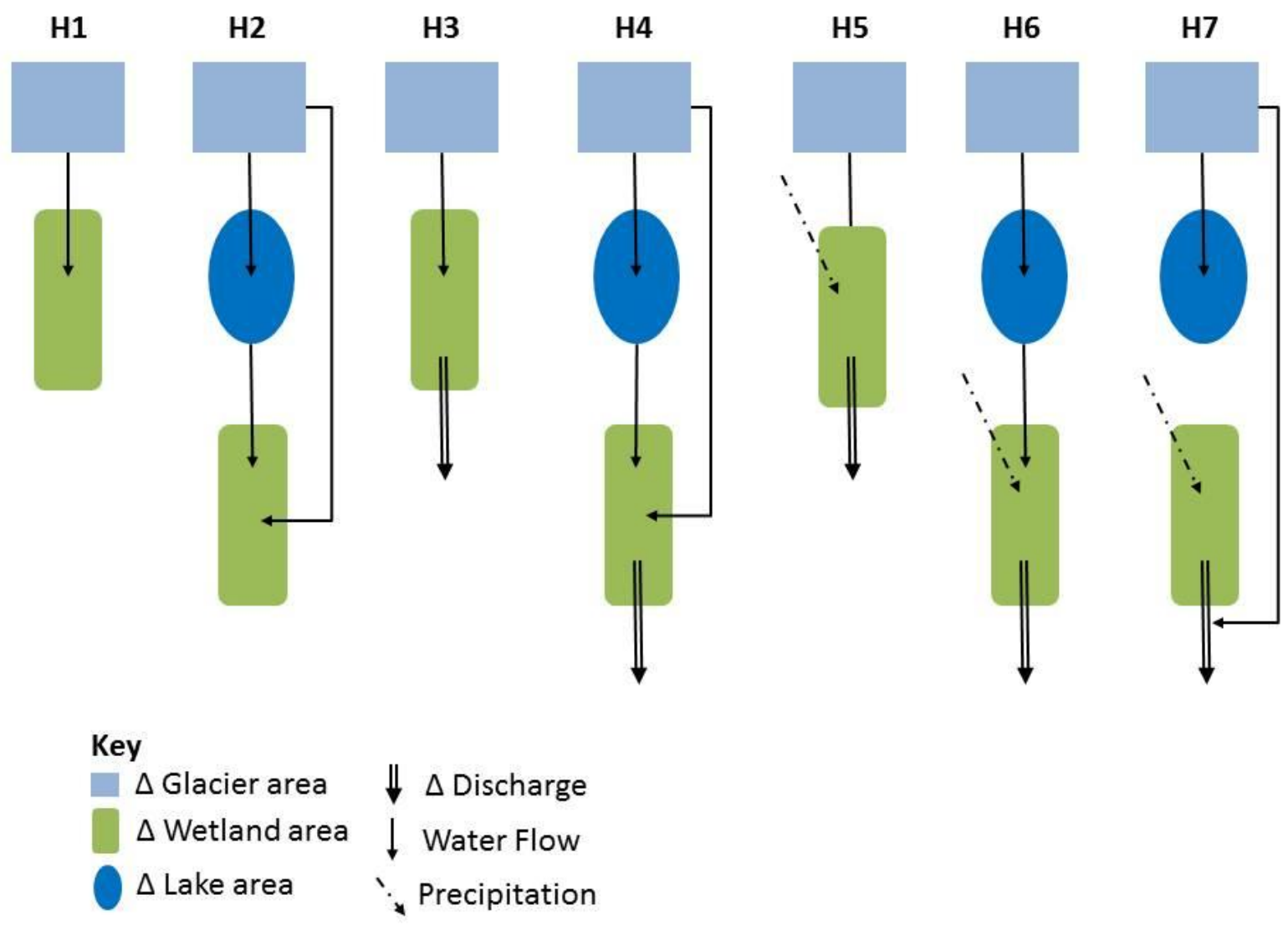

Figure 1. Representations of the possible spatial and hydrologic relationships among changing wetlands and other variables evaluated in this research.

\section{Study Area and Methods}

\subsection{Study Area}

The Cordillera Blanca mountain range is located between $8.5-10^{\circ} \mathrm{S}$ and $77^{\circ} 00^{\prime}-77^{\circ}$ 50 ' $\mathrm{W}$ and is oriented on a northwest-southeast axis. It is comprised of a series of parallel valleys, each its own watershed in the Santa River basin (Figure 2). The scale of analysis was the watershed level and we evaluated seven watersheds within the Santa River basin. All sample watersheds are located on the west side of the Cordillera Blanca and drain into the Santa River, which flows to the Pacific Ocean. Watersheds on the east side of the divide were not used 
because there were no available stream discharge records. The seven watersheds evaluated are representative of the mountain range and span the latitudinal gradient, and vary in size, glacier coverage, and wetland coverage. Wetlands occur at elevations > 3500 m.a.s.l. and are located

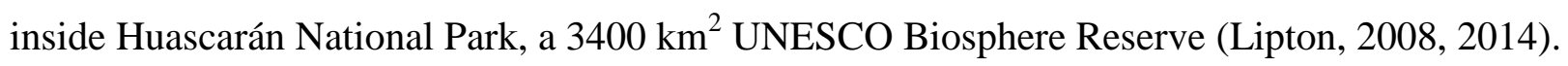
Based on field observations, wetlands in the study area included both highly organic peatlands and minerogenous wet meadows. Peatlands were dominated by plants including Plantago tubulosa, Eleocharis albibracteata, and Oritrophium limnophyllum, while wet meadows were dominated by Lachemilla pinnata, Agrostis breviculmis, and Lucilia kunthiana. 


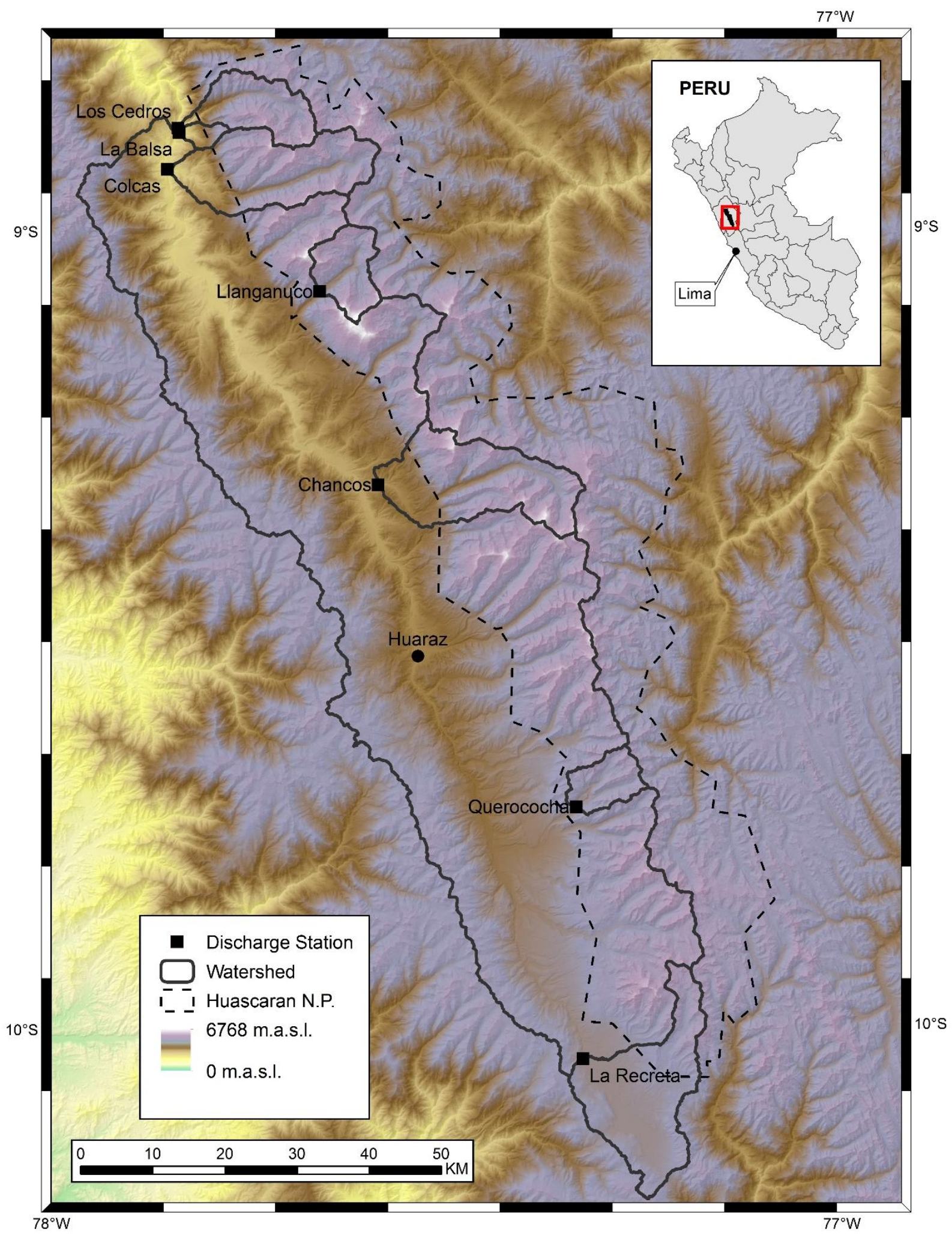

Figure 2. Study area showing the seven monitored watersheds, their discharge stations, Huascarán National Park, and proximity to the city of Huaraz in northern Peru. 


\subsection{Data and Analyses}

Data completeness, availability, and required variation between the two time periods were the parameters that determined 1987 and 1995 as the time interval studied. Discontinuous hydrological and meteorological observations in the Cordillera Blanca make temporal evaluations challenging and have prompted researchers to scale up effects of glacier recession from relatively small extents such as catchments to regional-scale watersheds (Mark et al., 2005). Near-constant heavy cloud cover during the wet season limits useable imagery captured by optical sensors like Landsat; wet season spatial and ecological dynamics are thus obscured. Spatial change in wetlands, glaciers, and lake areas were derived from classified Landsat TM images acquired on 15 May 1987 and 6 June 1995 (downloaded from http://glovis.usgs.gov), chosen because they are years in which all selected data (imagery, climate, and discharge records) are available and gap-free. Methods involved a two-stage process beginning first with extracting the response and explanatory variables (Table 2; pooled summary statistics in Table 3), followed by the first differencing analysis. 
Table 2. Variables and their descriptions.

\begin{tabular}{|c|c|c|c|}
\hline Variable & Symbol & Definition and Ecological Meaning & Unit \\
\hline \multicolumn{4}{|c|}{ RESPONSE } \\
\hline Wetland Area & WL_area & Area in catchment covered by wetland & ha \\
\hline \multicolumn{4}{|c|}{ EXPLANATORY } \\
\hline Glacier Area & Glacier_area & Area in watershed covered by snow/ice & ha \\
\hline Lake Area & Lake_area & Area in watershed covered by lake surface & ha \\
\hline $\begin{array}{l}\text { Mean Annual } \\
\text { Discharge }\end{array}$ & MeanAnnQ & $\begin{array}{l}\text { Mean annual discharge from the calendar year } \\
\text { coincident with image acquisition year }\end{array}$ & $\mathrm{m}^{3} / \mathrm{s}$ \\
\hline $\begin{array}{l}\text { 6-year Mean } \\
\text { Annual } \\
\text { Discharge }\end{array}$ & 6MeanAnnQ & $\begin{array}{l}\text { Mean annual discharge from the calendar year } 6 \\
\text { years prior to image acquisition year }(1981,1989)\end{array}$ & $\mathrm{m}^{3} / \mathrm{s}$ \\
\hline $\begin{array}{l}\text { Dry Season } \\
\text { Discharge }\end{array}$ & DryQ & $\begin{array}{l}\text { The total discharge from the dry season preceding } \\
\text { image acquisition dates (July and August 1986, } \\
\text { 1994) }\end{array}$ & $\mathrm{m}^{3} / \mathrm{s}$ \\
\hline $\begin{array}{l}\text { Wet Season } \\
\text { Discharge }\end{array}$ & WetQ & $\begin{array}{l}\text { The total discharge from the wet season preceding } \\
\text { image acquisition dates (February and March } \\
\text { 1987, 1995) }\end{array}$ & $\mathrm{m}^{3} / \mathrm{s}$ \\
\hline $\begin{array}{l}\text { Total Annual } \\
\text { Precipitation }\end{array}$ & PrePrior & $\begin{array}{l}\text { The total precipitation computed from the } 12 \\
\text { months preceding the image acquisition dates }\end{array}$ & $\mathrm{mm}$ \\
\hline $\begin{array}{l}\text { 6-year Total } \\
\text { Annual } \\
\text { Precipitation }\end{array}$ & 6prePrior & $\begin{array}{l}\text { The total precipitation computed from the } 12 \\
\text { months occurring } 6 \text { years preceding image } \\
\text { acquisition dates }(1981,1989)\end{array}$ & $\mathrm{mm}$ \\
\hline $\begin{array}{l}\text { Dry Season } \\
\text { Precipitation }\end{array}$ & preJulyAug & $\begin{array}{l}\text { Total precipitation from the dry season preceding } \\
\text { image acquisition dates (July and August 1986, } \\
\text { 1994) }\end{array}$ & $\mathrm{mm}$ \\
\hline $\begin{array}{l}\text { Wet Season } \\
\text { Precipitation }\end{array}$ & preFebMar & $\begin{array}{l}\text { Total precipitation from the wet season preceding } \\
\text { image acquisition dates (February and March } \\
\text { 1986, 1994) }\end{array}$ & $\mathrm{mm}$ \\
\hline
\end{tabular}


Table 3. Pooled summary statistics for all variables in 1987 and 1995.

* represents missing data for La Balsa in 1981. See text for explanation.

\begin{tabular}{|c|c|c|c|c|c|}
\hline Variable & Symbol & Mean & $\begin{array}{l}\text { Standard } \\
\text { Deviation }\end{array}$ & Minimum & Maximum \\
\hline Wetland Area & WL_area & 717.13 & 1303.65 & 39.96 & 3745.26 \\
\hline Glacier Area & Glacier_area & 7983.51 & $13,641.12$ & 238.32 & $43,834.86$ \\
\hline Lake Area & Lake_area & 335.46 & 494.39 & 66.06 & 1629.72 \\
\hline $\begin{array}{l}\text { Mean Annual } \\
\text { Discharge } \\
\text { 6-year Mean }\end{array}$ & MeanAnnQ & 15.17 & 28.42 & 1.52 & 86.31 \\
\hline $\begin{array}{l}\text { Annual } \\
\text { Discharge }\end{array}$ & 6MeanAnnQ & 10.08 & 22.90 & * & 89.16 \\
\hline $\begin{array}{l}\text { Dry Season } \\
\text { Discharge }\end{array}$ & DryQ & 6.00 & 9.72 & 0.29 & 32.06 \\
\hline $\begin{array}{l}\text { Wet Season } \\
\text { Discharge }\end{array}$ & WetQ & 26.21 & 50.40 & 2.89 & 155.48 \\
\hline $\begin{array}{l}\text { Total Annual } \\
\text { Precipitation } \\
\text { 6-year Total }\end{array}$ & PrePrior & 373.91 & 49.94 & 284.90 & 464.10 \\
\hline $\begin{array}{l}\text { Annual } \\
\text { Precipitation }\end{array}$ & 6PrePrior & 718.35 & 183.12 & 520.40 & 990.60 \\
\hline $\begin{array}{l}\text { Dry Season } \\
\text { Precipitation }\end{array}$ & PreJulyAug & 12.27 & 21.03 & 0.50 & 82.50 \\
\hline $\begin{array}{l}\text { Wet Season } \\
\text { Precipitation }\end{array}$ & PreFebMar & 142.29 & 54.28 & 72.90 & 222.40 \\
\hline
\end{tabular}

\subsubsection{Extracting the Variables}

For each date, two Level $1 \mathrm{~T}$ images (path-row 8-66, 8-67) from the dry season were mosaicked together. Level 1T processing provides systematic, radiometric, and geometric accuracy by using a digital elevation model; image co-registration is consistent and spatial errors are less than one-half of one pixel (Hansen \& Loveland, 2012). Images were analyzed independently post-classification, making atmospheric correction unnecessary (Song, Woodcock, Seto, Lenney, \& Macomber, 2001). A hybrid supervised-unsupervised image classification was performed (using ERDAS Imagine 2014), a technique that uses all 7 bands in $30 \mathrm{~m}$ spatial resolution; band 6 was resampled from 120 m to 30 m (Messina, Crews-Meyer, \& Walsh, 2000; 
Walsh et al., 2003). The classification technique was selected due to previous good performances in the study region (Kintz, Young, \& Crews-Meyer, 2006; Lipton, 2008; Postigo, Young, \& Crews, 2008). First, an unsupervised classification (ISODATA) clustered the spectral information into 255 signatures. These signatures were then evaluated using the transform divergence method, removing signatures with low separability. Next, the edited signatures were applied in a supervised classification. To improve the accuracy of difficult-to-classify wetlands, we added a 4-3 band ratio following Ozesmi and Bauer (2002). Lake colors vary widely due to suspended glacial flour in the study area, giving poor classifications; therefore, lakes were digitized manually and modified for each time period based on the GLIMS dataset (http://www.glims.org) (Kargel, Leonard, Bishop, Kääb, \& Raup, 2014). The final product was a categorical map for each date with seven land cover types: Barren, Puna, Wetland, Snow/Ice, Lake, Shadow, and Cloud; only Wetland, Snow/Ice, and Lake were used in this particular analysis. Accuracy assessments for the land cover classes were within standard norms of over 85\% (Congalton \& Green, 2008; Khorram, 1999). For 1987, overall accuracy was $89.38 \%$ and overall Kappa was $87.52 \%$. For 1995 , overall accuracy was $85.4 \%$ and overall Kappa was $82.3 \%$.

Precipitation and temperature variables were derived from the Climatic Research Unit dataset, CRU TS 3.10.01 (University of East Anglia Climatic Research Unit, Jones, \& Harris, 2013) and downloaded from CGIAR-CSI (http://www.cgiar-csi.org). CRU data offers deep temporal resolution from 1901 to 2010 for $0.5^{\circ}$ latitude/longitude grid cells. The CRU climate variables were originally synthesized from monthly observations from meteorological stations across the global terrestrial surface, excluding Antarctica (Harris, Jones, Osborn, \& Lister, 2014; Mitchell \& Jones, 2005); others have used these data for the study region (Urrutia \& Vuille, 
2009; Vuille et al., 2008) in spite of acknowledgements that the data should be used with caution because there are no inputs from weather stations in Peru and they may overestimate temperature. Data from nearby weather stations were unusable because of discontinuous observations. For 1987 and 1995, four precipitation variables were created that were meant to account for the lagged effect of surface flow and groundwater moving into peatlands (Table 2). For the 12 months preceding the image acquisition dates, total annual precipitation was calculated. We also calculated a 6-year lagged precipitation variable; it is the 12-month total annual precipitation prior to the image acquisition dates in 1981 and 1989. Wet season precipitation is the sum of the two months with historically highest precipitation, February and March (Baraer et al., 2012), preceding the image acquisition dates. Dry season precipitation was calculated from the sum of the two months preceding the image acquisition dates with the historically lowest precipitation, July and August. The temperature variable is the mean for the 12 months preceding the image acquisition date; due to inadequate variation across the two time periods, temperature was omitted from the final analysis. Where watersheds contained more than one CRU grid cell, the mean value was used.

Discharge data originated from a collection of records dating to the early 1950s, when an array of stream and precipitation gauges was installed in the Santa River basin. The historical dataset originally included daily time series for 17 stations, but after quality control analysis only nine stations were determined to be suitable for trend analysis (Baraer et al., 2012): Chancos, Colcas, La Balsa, La Recreta, Llanganuco, Los Cedros, Pachacoto, Parón, and Querococha. Of these 9 stations, 2 were eliminated for the present study because 1) Parón contains a glacial lake that is regulated by a drainage tunnel with flows intensively managed for hydroelectric power generation; and 2) the discharge record for Pachacoto was interrupted from 1992-1993 and in 
1995. A geographic information system (ArcGIS 10.2) was used with a digital elevation model (ASTER GDEM v.2 from http://gdem.ersdac.jspacesystems.or.jp/) to generate watersheds based on the coordinates of the seven discharge stations. Four stream discharge variables were calculated from the data (Table 2). Mean annual discharge and dry season discharge should be markers of the influence of glacier retreat on the hydrology of medium to large watersheds in the study area. Mean annual discharge is for the calendar year coinciding with the image date. Dry season discharge is defined as the total discharge for the 2 months with the historically lowest precipitation (July and August) coinciding with the image acquisition year. Wet season discharge is the total discharge for the 2 months with the historically highest precipitation (February and March) preceding the image acquisition date. Ideally, lagged discharge variables could be created for preceding years to account for residence times. In this case, only a 6-year lagged discharge variable was created (discharge from 1981 and 1989) because the only preceding years in which the discharge data were gap free were 1981 and 1989. Note that the La Balsa site was omitted because of missing data in 1981 so $n=6$ for this model only. The 6-year lagged variable was substituted into Model 3 and is referred to as Model 3A.

\subsubsection{First Differencing Regression}

For a panel dataset with observation $i$ and two time periods $(\mathrm{t}=1$ or 2$)$, the first differencing equation is expressed as:

$$
\begin{aligned}
& \mathrm{y}_{\mathrm{i} 2}=\left(\beta_{0}+\delta_{0}\right)+\beta_{1} \mathrm{x}_{\mathrm{i} 2}+\mathrm{a}_{\mathrm{i}}+\mathrm{u}_{\mathrm{i} 2}(\text { time }=2) \\
& \mathrm{y}_{\mathrm{i} 1}=\beta_{0}+\beta_{1} \mathrm{x}_{\mathrm{i} 1}+\mathrm{a}_{\mathrm{i}}+\mathrm{u}_{\mathrm{i} 1}(\text { time }=1)
\end{aligned}
$$

where $y_{i t}$ is the response variable of interest, $\beta_{0}$ is the $y$ intercept or constant, $\beta_{0}+\delta_{0}$ is the change in the intercept from time 1 to time $2, \beta_{1}$ is a coefficient of predictor variable $x, x_{i t}$ 
represents predictor variables, $a_{i}$ is the unobserved time constant factor (the unobserved effect), and $u_{i t}$ is the time-varying error (Wooldridge, 2009). After subtracting time 1 from time 2, the following equation results:

$$
\left(\mathrm{y}_{\mathrm{i} 2}-\mathrm{y}_{\mathrm{i} 1}\right)=\delta_{0}+\beta_{1}\left(\mathrm{x}_{\mathrm{i} 2}-\mathrm{x}_{\mathrm{i} 1}\right)+\left(\mathrm{u}_{\mathrm{i} 2}-\mathrm{u}_{\mathrm{i} 1}\right)
$$

or

$$
\Delta \mathrm{y}_{\mathrm{i}}=\delta_{0}+\beta_{1} \Delta \mathrm{x}_{\mathrm{i}}+\Delta \mathrm{u}_{\mathrm{i}}
$$

where $\Delta$ represents the change from time 1 to time 2 . The term 'first differencing' was coined because the unobserved effect, $a_{i}$, is 'differenced away' so that the time-constant unobserved effects are controlled for (Wooldridge, 2009, p. 458). The rationale is that time-constant variables are not likely to be factors driving change (Allison, 2009; Andreß et al., 2012); thus variables such as lithology and topography that are time-constant would not be included in the analysis. Statistical computations were conducted in STATA SE 12 using function xtreg and the fe option for fixed effects regression estimation. Robust standard errors are reported. Assumptions for fixed effects regression were not violated, implying that model estimates are efficient and unbiased in regards to exogeneity, homoscedasticity, serial correlation, and measurement error (Andreß et al., 2012). Multicollinearity was detected among the following variables: mean annual discharge, dry season discharge, and wet season discharge. Similarly, multicollinearity existed among previous precipitation and dry and wet season precipitation; therefore, models were restricted to mean annual discharge and previous precipitation. Model specifications were performed in two stages. First, bivariate regressions of change in wetland area on all the explanatory variables were computed. Second, regressions were completed following the hypotheses in Table 1 and Figure 1. The significance value selected was 
0.1 (two-tailed). For fixed effect regressions, STATA produces three $\mathrm{R}^{2}$ values: within, between, and overall. The within $\mathrm{R}^{2}$ is the most commonly used for interpreting first differencing regressions (Allison, 2009, p. 19), reporting the explained portion of the within variance using the mean deviation variables (Allison, 2009; Andreß et al., 2012). All $\mathrm{R}^{2}$ values reported herein are within $\mathrm{R}^{2} \mathrm{~s}$.

\section{Results}

Wetland change could be best predicted from changes in glacier area and mean annual discharge, although prior precipitation was also statistically significant (Tables 4, 5). First, the bivariate regressions were computed to test $\mathrm{H} 1$ and to determine whether or not any of the explanatory variables might individually explain change in wetland area. One variable, prior precipitation (PrePrior) was highly statistically significant $(\mathrm{p}<0.001$, two-tailed) and the within $\mathrm{R}^{2}$ was 0.5571 (Table 4). Results of the multivariate regressions that correspond to the hypotheses described in Table 1 and Figure 1 are reported in Table 5. Of the seven hypotheses, only H3 passed the stated acceptance criteria of $\mathrm{p}<0.1$; consequently, hypotheses 1,2 and 4 to 7 were rejected. Model 3 failed to be rejected and shows that change in glacier area and change in mean annual discharge were statistically significant at the 0.1 level (and borderline to 0.05 level), and within $\mathrm{R}^{2}$ was 0.3431 .

The first differencing regression used here indicated that change in glacier area and change in mean annual discharge were driving wetland change from 1987 to 1995. Results from Model 3 estimated that for every 1 ha decrease in glacier area, wetland area increased by 0.07 hectares, holding all other factors constant. For every $1 \mathrm{~m}^{3} \mathrm{~s}^{-1}$ increase in annual discharge, wetland area increased by 72 ha, holding all other factors constant. Relative to change in glacier area, change in mean annual discharge accounted for the largest magnitude of wetland change 
from 1987 to 1995 . This is consistent with the constant coefficient in Model 3 that was not statistically significantly different from zero. In other words, if glacier area was not changing (an absence of recession) and if stream discharge was not changing, we would expect change in wetland area in the study area to be minimal. In addition, results from the bivariate regression of change in prior precipitation on change in wetland area shows that there is a possibility that increased precipitation could increase wetland area, a concept we consider in the discussion section.

Furthermore, we wanted to explore a longer lagged discharge variable in the event that the 12 month lagged discharge variable, Mean Annual Discharge (Table 2), did not capture the interaction. In other words, is the hydrologic residence time longer than the 12 months preceding the image acquisition date? To address this question, a 6-year lagged discharge variable was created as described in the methods section. The 6-year lagged variable was substituted into Model 3 and is referred to as Model 3A. The analysis revealed that the 6-year lagged discharge variable did not improve the estimations (Table 6). Six year mean annual discharge and change in glacier area were not statistically significant and the $\mathrm{R}^{2}$ value declined to 0.0377 . Therefore, we concluded that the hydrologic residence time is not 6 years. It is possible that the residence time is shorter or longer and could be statistically significant, but our hydrologic dataset did not permit testing of other residence times because of data incompleteness (see Section 2.2.1.). 
Table 4. Bivariate regressions of change in wetland area on explanatory variables. Robust standard errors are shown. * Does not include La Balsa watershed; $n=6$

\begin{tabular}{|c|c|c|c|c|c|c|}
\hline & Constant & $\begin{array}{c}\text { Robust } \\
\text { SE }\end{array}$ & Coefficient & $\begin{array}{c}\text { Robust } \\
\text { SE }\end{array}$ & $\begin{array}{c}\mathbf{p} \\
\text { Value }\end{array}$ & $\begin{array}{c}\mathbf{R}^{2} \\
\text { Within }\end{array}$ \\
\hline $\begin{array}{l}\Delta \text { Glacier } \\
\text { Area }\end{array}$ & 712.4923 & 17.4413 & 0.0005 & 0.0022 & 0.799 & 0.0009 \\
\hline$\Delta$ Lake Area & 728.9068 & 28.7390 & -0.0351 & 0.0856 & 0.696 & 0.0035 \\
\hline $\begin{array}{c}\Delta \text { Mean } \\
\text { Annual Q }\end{array}$ & 684.5593 & 58.5739 & 2.1468 & 3.8604 & 0.598 & 0.0137 \\
\hline $\begin{array}{c}\Delta 6 \text { Yr Mean } \\
\text { Annual Q* }\end{array}$ & 223.8707 & 130.0444 & -2.5637 & 30.0275 & 0.935 & 0.0035 \\
\hline $\begin{array}{c}\Delta \text { Dry season } \\
\mathrm{Q}\end{array}$ & 719.7329 & 21.2511 & -0.4332 & 3.5414 & 0.907 & 0.0004 \\
\hline $\begin{array}{c}\Delta \text { Wet season } \\
\mathrm{Q}\end{array}$ & 696.8809 & 31.6755 & 0.7726 & 1.2085 & 0.546 & 0.0108 \\
\hline$\Delta$ PrePrior & -437.3186 & 157.0036 & 3.0874 & 0.4199 & 0.000 & 0.5571 \\
\hline $\begin{array}{c}\Delta 6 \text { Yr } \\
\text { PrePrior }\end{array}$ & 688.5121 & 61.4422 & 0.0398 & 0.0855 & 0.658 & 0.0421 \\
\hline $\begin{array}{c}\Delta \text { Pre July } \\
\text { Aug }\end{array}$ & 712.1690 & 5.3583 & 0.4042 & 0.4363 & 0.390 & 0.0278 \\
\hline$\Delta$ Pre Feb Mar & 701.4043 & 42.1073 & 0.1105 & 0.2959 & 0.722 & 0.0280 \\
\hline
\end{tabular}


Table 5. Model results for multiple regressions. Model numbers correspond with hypotheses described in

Table 1. Robust standard errors are reported in parentheses below each coefficient.

\begin{tabular}{|c|c|c|c|c|c|c|c|c|}
\hline & & Model 1 & Model 2 & Model 3 & Model 4 & Model 5 & Model 6 & Model 7 \\
\hline Constant & $\begin{array}{c}\text { Coeff } \\
\text { S.E. } \\
\text { p value }\end{array}$ & $\begin{array}{c}712.4923 \\
(17.4413) \\
0.000\end{array}$ & $\begin{array}{c}2327.0300 \\
(2397.4540) \\
0.369\end{array}$ & $\begin{array}{c}218.9284 \\
(219.3361) \\
0.357\end{array}$ & $\begin{array}{c}1262.1010 \\
(2139.7250) \\
0.577\end{array}$ & $\begin{array}{c}-566.9294 \\
(411.7595) \\
0.218\end{array}$ & $\begin{array}{c}-1279.7660 \\
(1823.6730) \\
0.509\end{array}$ & $\begin{array}{c}-504.7602 \\
(220.8903) \\
0.062\end{array}$ \\
\hline $\begin{array}{c}\Delta \text { Glacier } \\
\text { Area }\end{array}$ & $\begin{array}{c}\text { Coeff } \\
\text { S.E. } \\
\text { p value }\end{array}$ & $\begin{array}{c}0.0005 \\
(0.0022) \\
0.799\end{array}$ & $\begin{array}{c}-0.0874 \\
(0.1303) \\
0.527\end{array}$ & $\begin{array}{c}-0.0743 \\
(0.0303) \\
0.050\end{array}$ & $\begin{array}{c}-0.1207 \\
(0.0694) \\
0.133\end{array}$ & $\begin{array}{c}.01851 \\
(0.0860) \\
0.837\end{array}$ & $\begin{array}{c}0.0582 \\
(0.1006) \\
0.584\end{array}$ & \\
\hline$\Delta$ Lake Area & $\begin{array}{c}\text { Coeff } \\
\text { S.E. } \\
\text { p value }\end{array}$ & & $\begin{array}{c}-2.7187 \\
(4.0455) \\
0.527\end{array}$ & & $\begin{array}{c}-1.6717 \\
(3.1715) \\
0.617\end{array}$ & & $\begin{array}{c}0.9693 \\
(2.5702) \\
0.719\end{array}$ & \\
\hline $\begin{array}{c}\Delta \text { Mean } \\
\text { Annual Q }\end{array}$ & $\begin{array}{c}\text { Coeff } \\
\text { S.E. } \\
\text { p value }\end{array}$ & & & $\begin{array}{c}71.9332 \\
(30.4054) \\
0.056\end{array}$ & $\begin{array}{c}64.5858 \\
(40.2777) \\
0.160\end{array}$ & $\begin{array}{c}-22.1651 \\
(86.5298) \\
0.806\end{array}$ & $\begin{array}{c}-30.8301 \\
(81.0252) \\
0.717\end{array}$ & $\begin{array}{c}-3.8722 \\
(2.9604) \\
0.239\end{array}$ \\
\hline$\Delta$ Pre Prior & $\begin{array}{c}\text { Coeff } \\
\text { S.E. } \\
\text { p value }\end{array}$ & & & & & $\begin{array}{c}3.9381 \\
(2.6804) \\
0.192\end{array}$ & $\begin{array}{c}4.4791 \\
(2.6185) \\
0.138\end{array}$ & $\begin{array}{c}3.4249 \\
(0.6652) \\
0.002\end{array}$ \\
\hline $\mathrm{R}^{2}$ Within & & 0.0009 & 0.1334 & 0.3431 & 0.3896 & 0.6159 & 0.6264 & 0.6088 \\
\hline
\end{tabular}


Table 6. Results for fixed difference regressions on Model 3 and 3A. Model 3A excluded La Balsa $(n=6)$ and substituted a 6-year lagged discharge variable for 12-month discharge variable.

Model numbers correspond with hypotheses described in table 1. Robust standard errors are reported in parentheses below each coefficient.

\begin{tabular}{cccc} 
& & Model 3 & Model 3A \\
\hline Constant & Coeff & 188.7638 & 175.0493 \\
& S.E. & $(143.7029)$ & $(183.5832)$ \\
& p value & 0.246 & 0.384 \\
\hline$\Delta$ Glacier & Coeff & -0.1229 & 0.0399 \\
Area & S.E. & $(0.0743)$ & $(0.1068)$ \\
& p value & 0.159 & 0.723 \\
\hline$\Delta$ Mean & Coeff & 88.5584 & \\
Annual Q & S.E. & $(34.8529)$ & \\
& p value & 0.052 & \\
\hline$\Delta$ Mean & Coeff & & -16.4203 \\
Annual Q 6 & S.E. & & $(46.1591)$ \\
& p value & & 0.737 \\
\hline $\mathrm{R}^{2}$ Within & & 0.4110 & 0.0377 \\
\hline
\end{tabular}

\section{Discussion}

Connectivity between land change and hydrologic processes are not well understood in tropical mountain regions, but the methods and results presented here show that a spatially explicit econometric analysis demonstrates a promising approach that can be further developed and used by land change scientist and land managers preparing for change associated with glacier recession. We are aware of only one other study located in the tropics that investigated the connections between landscape and hydrology. Mosquera and others (2015) used linear regression to estimate the relationship between stream runoff and wetlands in the Ecuadorian páramo. They found that larger wetlands are associated with higher stream discharge. Our findings are consistent with Mosquera and others (2015) because we show that wetland area and discharge are linked; however, our innovation is the adoption of first differencing regression that 
incorporates a temporal variable. Adding in the element of temporal change and attempting to elucidate causality is crucial for research in highland landscapes because they are experiencing spatial transformation that will impact ecosystem services. Sociologists have used first differencing regression to evaluate environmental change as it relates to shifts in populations, economic forces, and other factors (Jorgenson and Clark, 2011; Clement and Podowski, 2013; Clement et al., 2014), but we are not aware of any other applied study that uses spatially explicit biophysical variables to examine connectivity between hydrology and landscape change.

The indications that changing glacier area and changes in mean annual discharge were associated with change in wetland area could be evaluated within the context of the peak water concept. Using the same discharge data used here, Baraer et al. (2012) found the watersheds were already past peak water and discharge had begun its decline by the 1980s. All seven watersheds evaluated were experiencing decreasing discharge and higher variability. Wetland area decreased from 2000-2011 in one valley in the Cordillera Blanca as reported in Bury et al. (2013); findings by Polk (2016) show wetland area increased from 1987 to 1999, then decreased in area from 1999 to 2010. These two observations suggest that wetlands follow the peak water curve, but with a possible time lag as illustrated in Figure 3. Projected further decreases in hydrological input into wetlands in the future can be expected to result in their degradation and soil desiccation. The effects of reduced hydrological input should be observable on the spatial distribution and configuration of wetland patches. Spatial effects may include wetland fragmentation, attrition, dissection, shrinkage, and perforation. These patch modifications would likely result in associated ecological effects including loss of species adapted to or dependent on saturated substrates (Lee et al., 2015; Quenta et al., 2016). Ecosystem services provided by the wetlands, such as carbon and water storage, nutrient filtration, and biomass production would 
decrease (Charman, 2002; Dise, 2009) while atmospheric radiative forcing would potentially increase (Petrescu et al., 2015). Figure 3 shows the contemporaneous effects of changing wetland area on ecosystem services. Changes in wetland geomorphic processes and vegetation composition could also occur as spatial changes take place and represent an opportunity for future research.

The estimates reported here hold true for 1987 to 1995 in our study area, but would likely differ if a nonlinear relationship between mean annual discharge and change in wetland area is generally expected over a longer period that would exceed satellite and hydrologic observation records. In deglaciating watersheds, research (Barnett, Adam, \& Lettenmaier, 2005; Mark \& Seltzer, 2003; Milner, Brown, \& Hannah, 2009) predicted that precipitation will increasingly control watershed hydrology because the effect of glacier meltwater will diminish. The statistically significant relationships between changes in wetland area and prior 12-month precipitation (PrePrior) supports these previous predictions and suggests that ecosystems may already be responding to losses in ice cover ( $\mathrm{p}$-value $=0.000$, within $\mathrm{R}^{2}$ is 0.5571 , Table 4 ). Wetlands in the study area are a complex of bogs, fens, and minerogenous meadows and based on our results, the wetlands remaining in some watersheds may be transitioning to an increased dominance of precipitation-dependent bogs. With the implementation of a continuous hydrologic monitoring network, future research could take into account the influences of other wetland water sources such as groundwater and surface water flows. Over decadal time scales, glacier recession will likely trigger changes in vegetation cover (Young et al., 2017) and soils; future research should evaluate the linkages and feedback mechanisms between changes in vegetation, soils, and hydrology in tropical mountain landscapes. 


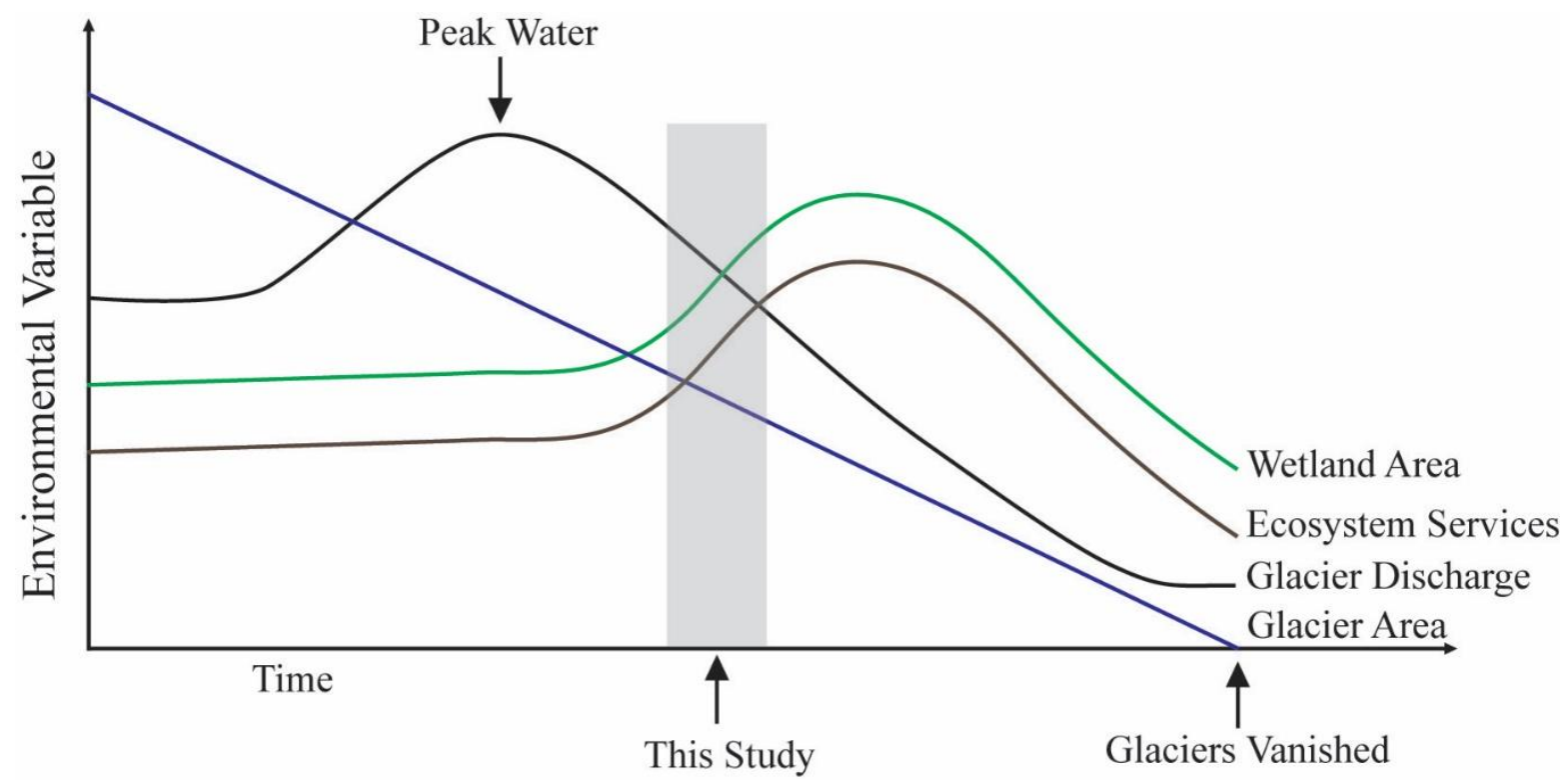

Figure 3. The proposed relationships among peak water, glacier recession, changing glacier discharge, wetland area, and wetland ecosystem services with the approximate period of this study indicated by the grey shaded area.

\section{Conclusion}

Decadal evaluations of other similar high mountain ecosystems show that wetland area may increase (H. Li, Xu, \& Zhao, 2014; Postigo et al., 2008), decrease (Bury et al., 2013; Z. W. Li et al., 2015; Nie \& Li, 2011), exhibit stasis (Gao, Li, \& Brierley, 2012), or both increase and decrease (Yao, Zhao, Gao, Sun, \& Li, 2011). More could be done to evaluate effects of hydrologic connectivity (DeFries and Eshelman 2004, Wohl et al.2012), especially in light of the possible nonlinear relationships implied by a peak water hydrograph expected during glacier retreat (Figure 3). The first differencing regression approach used in this study provides an analytical framework useful in situations where climate change or altered hydrological regimes may drive land cover transformations. Integrating additional econometric methods into land change science will facilitate further interactions among researchers interested in socioecological and socio-hydrological systems that may be vulnerable to climate change (Carey et al., 2014; Chapin, Kofinas, \& Folke, 2009). Unexpected interactions can be revealed and here 
showed that wetlands change with glacier retreat and stream discharge dynamics, but the influence of these variables may diminish as future glacier cover decreases and precipitation becomes the main driving force of wetland spatial change.

\section{Acknowledgments}

This work was funded by National Science Foundation under the Coupled Human and Natural Systems Program ("Hydrologic Transformation and Human Resilience to Climate Change in the Peruvian Andes" Award Number 1010381); the National Science Foundation under the Doctoral Dissertation Research Improvement Grant (“Glacier Recession and Implications for HighElevation Peatlands" Award Number 1333141); the University of Texas Department of Geography and the Graduate School; and the American Association of Geographers Mountain Specialty Group (Chimborazo Student Research Grant). Molly H. Polk and Kenneth R. Young are grateful for inspiration from Eugenio Y. Arima and fellow participants in Regression Analysis in Geography. The authors thank Thomas Christiansen for assistance with Figure 3. We are also appreciative of valuable comments from two anonymous reviewers.

\section{References}

Allison, P.D. (2009). Fixed Effects Regression Models. Thousand Oaks, CA: SAGE Publications, Inc.

Andreß, H.J., Golsch, K., \& Schmidt, A. (2012). Applied Panel Data Analysis for Economic and Social Surveys (1st ed.). Dordrecht: Springer.

Baraer, M., Mark, B.G., McKenzie, J.M., Condom, T., Bury, J., Huh, K.I., ... Rathay, S. (2012). Glacier recession and water resources in Peru's Cordillera Blanca. Journal of Glaciology, 58, 134-150. doi: 10.3189/2012JoG11J186

Barnett, T.P., Adam, J. C., \& Lettenmaier, D.P. (2005). Potential impacts of a warming climate on water availability in snow-dominated regions. Nature, 438, 303-309. doi: 10.1038/nature04141

Bradley, R.S., Vuille, M., Diaz, H.F., Vergara, W. (2006) Threats to water supplies in the 
tropical Andes. Science, 312, 1755-1756. doi: 10.1126/science.1128087

Braun, L.N., Weber, M., \& Schulz, M. (2000). Consequences of climate change for runoff from Alpine regions. Annals of Glaciology, 31, 19-25. doi:10.3189/172756400781820165

Burns, P., \& Nolin, A. (2014). Using atmospherically-corrected Landsat imagery to measure glacier area change in the Cordillera Blanca, Peru from 1987 to 2010. Remote Sensing of Environment, 140, 165-178. doi: 10.1016/j.rse.2013.08.026

Bury, J., Mark, B.G., Carey, M., Young, K.R., McKenzie, J., Baraer, M., ... Polk, M.H. (2013). New geographies of water and climate change in Peru: Coupled natural and social transformations in the Santa River watershed. Annals of the Association of American Geographers, 103, 363-374. doi: 10.1080/00045608.2013.754665

Carey, M., Baraer, M., Mark, B.G., French, A., Bury, J., Young, K R., \& McKenzie, J.M. (2014). Toward hydro-social modeling: Merging human variables and the social sciences with climate-glacier runoff models (Santa River, Peru). Journal of Hydrology, 518, 6070. doi:10.1016/j.jhydrol.2013.11.006

Chapin, F.S., Kofinas, G.P., \& Folke, C. (Eds.). (2009). Principles of Ecosystem Stewardship: Resilience-Based Natural Resource Management in a Changing World. New York: Springer.

Charman, D. J. (2002). Peatlands and Environmental Change. New York: J. Wiley \& Sons Ltd.

Chowdhury, R.R. (2006). Driving forces of tropical deforestation: The role of remote sensing and spatial models. Singapore Journal of Tropical Geography, 27, 82-101. doi:10.1111/j.1467-9493.2006.00241.x

Clement, M.T., Ergas, C., \& Greiner, P.T. (2014). The environmental consequences of rural and urban population change: An exploratory spatial panel study of forest cover in the southern United States, 2001-2006. Rural Sociology, 80, 108-36. doi:10.1111/ruso.12056.

Clement, M.T., \& E. Podowski. (2013). Intensifying the countryside: A sociological study of cropland lost to the built environment in the United States, 2001-2006. Social Forces, 92, 815-38. doi:10.1093/sf/sot097.

Collins, D.N. (2008). Climatic warming, glacier recession and runoff from Alpine basins after the Little Ice Age maximum. Annals of Glaciology, 48, 119-124. doi:10.3189/172756408784700761

Congalton, R.G., \& Green, K. (2008). Assessing the Accuracy of Remotely Sensed Data: Principles and Practices. Hoboken, N.J.: Taylor \& Francis Ltd.

Cooper, D.J., Wolf, E., Colson, C., Vering, W., Granda, A., \& Meyer, M. (2010). Alpine peatlands of the Andes, Cajamarca, Peru. Arctic, Antarctic, and Alpine Research, 42, 19 33. doi:10.1657/1938-4246-42.1.19

Cui, L., Gao, C., Zhou, D., \& Mu, L. (2014). Quantitative analysis of the driving forces causing declines in marsh wetland landscapes in the Honghe region, northeast China, from 1975 to 2006. Environmental Earth Sciences, 71, 1357-1367. doi:10.1007/s12665-013-2542-5

DeFries, R., \& Eshleman, K.N. (2004). Land-use change and hydrologic processes: A major focus for the future. Hydrological Processes, 18, 2183-2186. doi:10.1002/hyp.5584

Dise, N. B. (2009). Peatland response to global change. Science, 326, 810-811. doi: 10.1126/science. 1174268

Emmer, A., Vilímek, V., Klimeš, J., \& Cochachin, A. (2014). Glacier retreat, lakes development and associated natural hazards in Cordilera Blanca, Peru. In W. Shan, Y. Guo, F. Wang, H. Marui, \& A. Strom (Eds.), Landslides in Cold Regions in the Context of Climate 
Change (pp. 231-252). Switzerland: Springer International Publishing.

Gao, J., Li, X., \& Brierley, G. (2012). Topographic influence on wetland distribution and change in Maduo County, Qinghai-Tibet Plateau, China. Journal of Mountain Science, 9, 362371. doi:10.1007/s11629-009-2263-0

Gordon, R. P., Lautz, L. K., McKenzie, J. M., Mark, B. G., Chavez, D., \& Baraer, M. (2015). Sources and pathways of stream generation in tropical proglacial valleys of the Cordillera Blanca, Peru. Journal of Hydrology, 522, 628-644. http://doi.org/10.1016/j.jhydrol.2015.01.013

Hansen, M. C., \& Loveland, T. R. (2012). A review of large area monitoring of land cover change using Landsat data. Remote Sensing of Environment, 122, 66-74. doi:10.1016/j.rse.2011.08.024

Harris, I., Jones, P.D., Osborn, T.J., \& Lister, D.H. (2014). Updated high-resolution grids of monthly climatic observations - the CRU TS3.10 Dataset. International Journal of Climatology, 34, 623-642. doi:10.1002/joc.3711

Hock, R., Jansson, P., \& Braun, L.N. (2005). Modelling the response of mountain glacier discharge to climate warming. In U.M. Huber, H.K.M. Bugmann, \& M.A. Reasoner (Eds.), Global Change and Mountain Regions: An overview of current knowledge (pp. 243-252). The Netherlands: Springer. doi: 10.1007/1-4020-3508-X

Jansson, P., Hock, R., \& Schneider, T. (2003). The concept of glacier storage: A review. Journal of Hydrology, 282, 116-129. doi:10.1016/S0022-1694(03)00258-0

Jorgenson, A.K, \& Clark, B. (2011). Societies consuming nature: A panel study of the ecological footprints of nations, 1960-2003. Social Science Research, 40, 226-244. doi:10.1016/j.ssresearch.2010.09.004

Juen, I., Kaser, G., \& Georges, C. (2007). Modelling observed and future runoff from a glacierized tropical catchment (Cordillera Blanca, Perú). Global and Planetary Change, 59, 37-48. doi:10.1016/j.gloplacha.2006.11.038

Kargel, J.S., Leonard, G.J., Bishop, M.P., Kääb, A., \& Raup, B.H. (Eds.). (2014). Global Land Ice Measurements from Space (2014 ed.). New York: Springer.

Kaser, G. (1999). A review of the modern fluctuations of tropical glaciers. Global and Planetary Change, 22, 93-103. doi:10.1016/S0921-8181(99)00028-4

Kaser, G., Ames, A., \& Zamora, M. (1990). Glacier fluctuations and climate in the Cordillera Blanca. Annals of Glaciology, 141, 136-140. Retrieved from http://www.igsoc.org/annals/

Khorram, S. (Ed.). (1999). Accuracy Assessment of Remote Sensing-Derived Change Detection. Bethesda, MD: American Society for Photogrammetry and Remote Sensing.

Kintz, D. B., Young, K.R., \& Crews-Meyer, K.A. (2006). Implications of land use/land cover change in the buffer zone of a national park in the tropical Andes. Environmental Management, 38, 238-252. doi:10.1007/s00267-005-0147-9

Lee, S.Y., Ryan, M.E., Hamlet, A.F., Palen, W J., Lawler, J.J., \& Halabisky, M. (2015). Projecting the hydrologic impacts of climate change on montane wetlands. PLoS ONE, 10(9), e0136385. doi:10.1371/journal.pone.0136385

Li, H., Xu, D., \& Zhao, Y. (2014). Peatland area change in the southern Altay Mountains over the last twenty years based on GIS and RS analysis. Frontiers of Earth Science, 8, 558563. doi:10.1007/s11707-014-0436-9

Li, Z.W., Wang, Z.Y., Brierley, G., Nicoll, T., Pan, B.Z., \& Li, Y.F. (2015). Shrinkage of the Ruoergai Swamp and changes to landscape connectivity, Qinghai-Tibet Plateau. 
CATENA, 126, 155-163. doi:10.1016/j.catena.2014.10.035

Lipton, J.K. (2008). Human Dimensions of Conservation, Land Use, and Climate Change in Huascaran National Park, Peru. Doctoral Dissertation. Retrieved from http://www.lib.utexas.edu/.

Lipton, J.K. (2014). Lasting legacies: Conservation and communities at Huascarán National Park, Peru. Society \& Natural Resources, 27, 820-833. doi:10.1080/08941920.2014.905888

Maldonado Fonkén, M.S. (2015). An introduction to the bofedales of the Peruvian High Andes. Mires \& Peat, 15, Article 5. Retrieved from www.mires-and-peat.net/

Mark, B.G., McKenzie, J.M., \& Gómez, J. (2005). Hydrochemical evaluation of changing glacier meltwater contribution to stream discharge: Callejon de Huaylas, Peru. Hydrological Sciences Journal, 50, 975-987. doi:10.1623/hysj.2005.50.6.975

Mark, B.G., \& Seltzer, G.O. (2003). Tropical glacier meltwater contribution to stream discharge: A case study in the Cordillera Blanca, Peru. Journal of Glaciology, 49, 271-281. doi:10.3189/172756503781830746

Mertens, B., \& Lambin, E.F. (2000). Land-cover change trajectories in Southern Cameroon. Annals of the Association of American Geographers, 90, 467-494. doi:10.1111/00045608.00205

Messina, J.P., Crews-Meyer, K.A., \& Walsh, S.J. (2000). Scale dependent pattern metrics and panel data analysis as applied in a multiphase hybrid landcover classification scheme. In ASPRS Conference Proceedings. Washington, D.C.

Milner, A.M., Brown, L.E., \& Hannah, D.M. (2009). Hydroecological response of river systems to shrinking glaciers. Hydrological Processes, 23, 62-77. doi:10.1002/hyp.7197

Mitchell, T.D., \& Jones, P.D. (2005). An improved method of constructing a database of monthly climate observations and associated high-resolution grids. International Journal of Climatology, 25, 693-712. doi:10.1002/joc.1181

Moore, R.D., Fleming, S.W., Menounos, B., Wheate, R., Fountain, A., Stahl, K., ... Jakob, M. (2009). Glacier change in western North America: Influences on hydrology, geomorphic hazards and water quality. Hydrological Processes, 23, 42-61. doi:10.1002/hyp.7162

Mosquera, G.M., Lazo, P.X, Célleri, R. Wilcox, B.P. Crespo, P. (2015). Runoff from tropical alpine grasslands increases with areal extent of wetlands. Catena, 125, 120-128. doi: 10.1016/j.catena.2014.10.010.

Nie, Y., \& Li, A. (2011). Assessment of alpine wetland dynamics from 1976-2006 in the vicinity of Mount Everest. Wetlands, 31, 875-884. doi:10.1007/s13157-011-0202-7

Nolin, A.W., Phillippe, J., Jefferson, A., \& Lewis, S.L. (2010). Present-day and future contributions of glacier runoff to summertime flows in a Pacific Northwest watershed: Implications for water resources. Water Resources Research, 46. doi:10.1029/2009WR008968/full

Ozesmi, S.L., \& Bauer, M.E. (2002). Satellite remote sensing of wetlands. Wetlands Ecology and Management, 10, 381-402. doi:10.1023/A:1020908432489

Petrescu, A.M.R., Lohila, A., Tuovinen, J.P., Baldocchi, D.D., Desai, A. R., Roulet, N. T., ... others. (2015). The uncertain climate footprint of wetlands under human pressure. Proceedings of the National Academy of Sciences, 112, 4594-4599. doi:10.1073/pnas.1416267112

Polk, M.H. (2016). "They are Drying Out": Social-Ecological Consequences of Glacier Recession on Mountain Peatlands in Huascaran National Park, Peru Doctoral 
Dissertation. Retrieved from http://www.lib.utexas.edu/.

Ponette-González, A.G., Marín-Spiotta, E., Brauman, K.A., Farley, K.A., Weathers, K.C., \& Young, K.R. (2014). Hydrologic connectivity in the high-elevation tropics:

Heterogeneous responses to land change. BioScience, 64, 92-104.

doi:10.1093/biosci/bit013

Postigo, J.C., Young, K.R., \& Crews, K.A. (2008). Change and continuity in a pastoralist community in the high Peruvian Andes. Human Ecology, 36, 535-551. doi:10.1007/s10745-008-9186-1

Pouyaud, B., Zapata, M., Yerreb, J., Gomez, J., Rosas, G., Suarez, W., \& Ribstein, P. (2005). On the future of the water resources from glacier melting in the Cordillera Blanca, Peru. Hydrological Science Journal, 50, 999-1022. doi:10.1623/hysj.2005.50.6.999

Quenta, E., Molina-Rodriguez, J., Gonzales, K., Rebaudo, F., Casas, J., Jacobsen, D., \& Dangles, O. (2016). Direct and indirect effects of glaciers on aquatic biodiversity in high Andean peatlands. Global Change Biology. doi:10.1111/gcb.13310

Rabatel, A., Francou, B., Soruco, A., Gomez, J., Cáceres, B., Ceballos, J.L., ... Huggel, C. (2013). Current state of glaciers in the tropical Andes: A multi-century perspective on glacier evolution and climate change. The Cryosphere, 7, 81-102. doi:10.5194/tc-7-812013

Rees, H.G., \& Collins, D.N. (2006). Regional differences in response of flow in glacier-fed Himalayan rivers to climatic warming. Hydrological Processes, 20, 2157-2169. doi: 10.1002/hyp.6209

Rydin, H., \& Jeglum, J.K. (2013). The Biology of Peatlands. Oxford: Oxford University Press.

Song, C., Woodcock, C., Seto, K., Lenney, M., \& Macomber, S. (2001). Classification and change detection using Landsat TM data: When and how to correct atmospheric effects? Remote Sensing of Environment, 75, 230-244. doi:10.1016/S0034-4257(00)00169-3

Thompson, L.G., Mosley-Thompson, E., Brecher, H., Davis, M., León, B., Les, D., ... Mountain, K. (2006). Abrupt tropical climate change: Past and present. Proceedings of the National Academy of Sciences of the United States of America, 103, 10536-10543. doi:10.1073/pnas.0603900103

University of East Anglia Climatic Research Unit, Jones, P. D., \& Harris, I. (2013). CRU TS3.10: Climatic Research Unit (CRU) Time-Series (TS) Version 3.10 of High Resolution Gridded Data of Month-by-month Variation in Climate (Jan. 1901 - Dec. 2009). NCAS British Atmospheric Data Centre. Retrieved from http://catalogue.ceda.ac.uk/uuid/ac3e6be017970639a9278e64d3fd5508

Urrutia, R., \& Vuille, M. (2009). Climate change projections for the tropical Andes using a regional climate model: Temperature and precipitation simulations for the end of the $21 \mathrm{st}$ century. Journal of Geophysical Research: Atmospheres, 114(D2), D02108. doi:10.1029/2008JD011021

Viviroli, D., Dürr, H.H., Messerli, B., Meybeck, M., Weingartner, R. (2007). Mountains of the world, water towers for humanity: Typology, mapping, and global significance. Water Resources Research, 43, W07447. doi: 10.1029/2006WR005653

Vuille, M., Kaser, G., \& Juen, I. (2008). Glacier mass balance variability in the Cordillera Blanca, Peru and its relationship with climate and the large-scale circulation. Global and Planetary Change, 62, 14-28. doi:10.1016/j.gloplacha.2007.11.003

Walsh, S.J., Bilsborrow, R.E., McGregor, S.J., Frizzelle, B.G., Messina, J.P., Pan, W.K., ... Baquero, F. (2003). Integration of longitudinal surveys, remote sensing time series, and 
spatial analyses. In J. Fox, R. Rindfuss, S. Walsh, \& V. Mishra (Eds.), People and the Environment. Approaches for Linking Household and Community Surveys to Remote Sensing and GIS (pp. 91-130). Boston, MA: Kluwer.

Wohl, E., Barros, A., Brunsell, N., Chappell, N.A., Coe, M., Giambelluca, T., ... others. (2012). The hydrology of the humid tropics. Nature Climate Change, 2, 655-662. doi:10.1038/nclimate 1556

Wooldridge, J.M. (2009). Introductory Econometrics: A modern approach (4th ed.). Mason, Ohio: South-Western Cengage Learning.

Yao, L., Zhao, Y., Gao, S., Sun, J., \& Li, F. (2011). The peatland area change in past 20 years in the Zoige Basin, eastern Tibetan Plateau. Frontiers of Earth Science, 5, 271-275. doi:10.1007/s11707-011-0178-x

Young, K.R., Ponette-Gonzáles, A.G., Polk, M.H., Lipton, J.K. (2017). Snowlines and treelines in the tropical Andes. Annals of the American Association of Geographers. n.p. doi: 10.1080/24694452.2016.1235479 


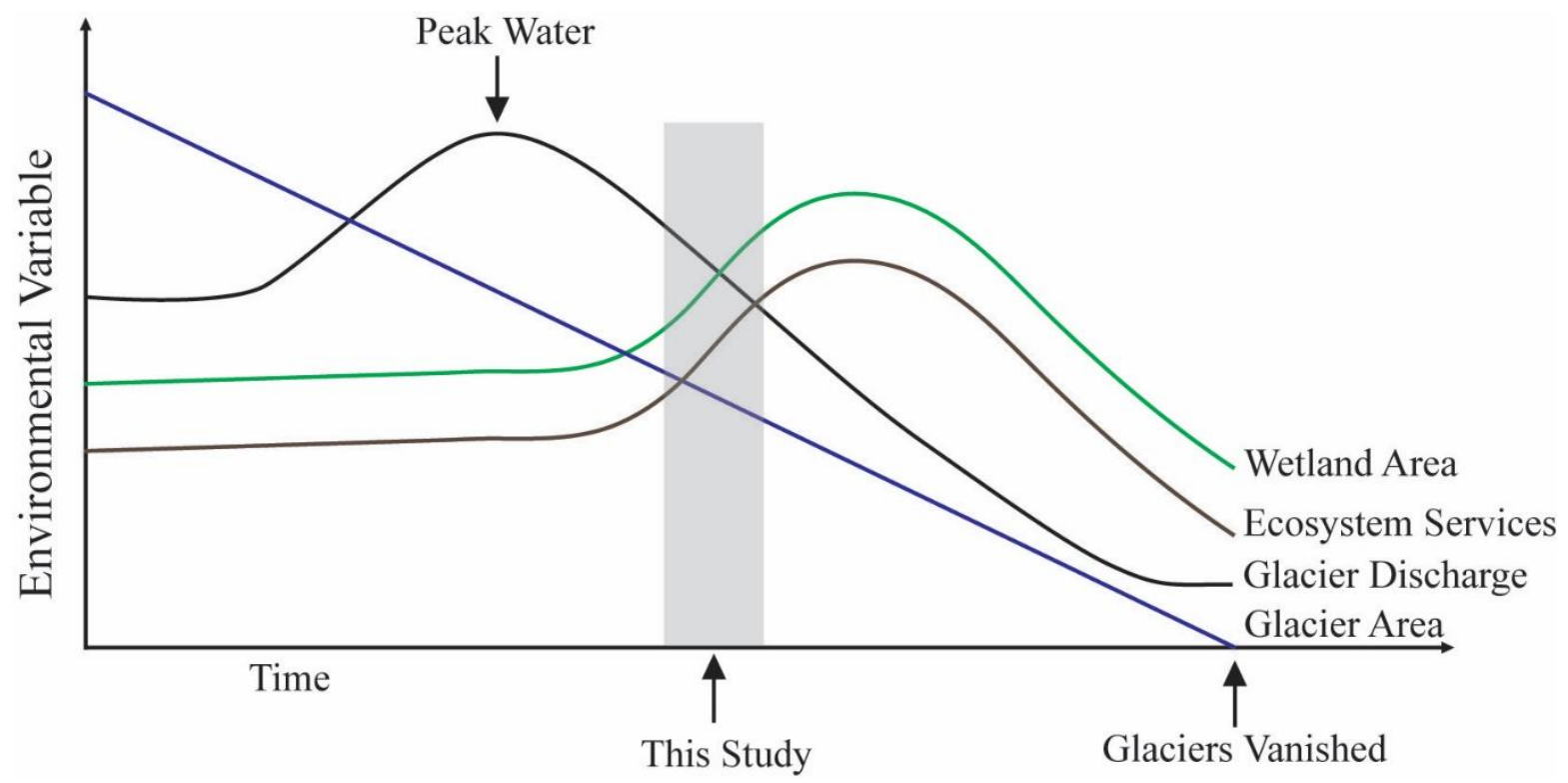

Graphical Abstract. This research proposes relationships among peak water, glacier recession, changing glacier discharge, wetland area, and wetland ecosystem services with the approximate period of this study indicated by the grey shaded area. 